\title{
Proximate Composition and Phytochemical Screenings of Crotalaria retusa Leaves and Seeds
}

\author{
J. A. Alalade ${ }^{*}$, J. A. Akinlade², A. A. Akingbade², C. B. Emiola1, I. A. Adebisi1 \\ ${ }^{1}$ Department of Animal Health and Production Technology, Oyo State College of Agriculture and Technology, Igboora, \\ Oyo State, Nigeria \\ ${ }^{2}$ Department of Animal Production and Health, Ladoke Akintola University of Technology, Ogbomoso, \\ Oyo State, Nigeria \\ Email: *alaladeja16@gmail.com
}

How to cite this paper: Alalade, J.A., Akinlade, J.A., Akingbade, A.A., Emiola, C.B. and Adebisi, I.A. (2019) Proximate Composition and Phytochemical Screenings of Crotalaria retusa Leaves and Seeds. Open Access Library Journal, 6: e5058.

https://doi.org/10.4236/oalib.1105058

Received: November 19, 2018

Accepted: January 27, 2019

Published: January 30, 2019

Copyright $\odot 2019$ by author(s) and Open Access Library Inc.

This work is licensed under the Creative Commons Attribution International License (CC BY 4.0).

http://creativecommons.org/licenses/by/4.0/

\begin{abstract}
The leaves and seeds of Crotalaria retusa were evaluated for the proximate, mineral and anti-nutritional contents in a completely randomized design. Atomic absorption spectrometry was used in determination of the seeds and leaves for phosphorus, potassium, magnesium, calcium and iron. Anti-nutritional factors (ANFs) including tannin, oxalate and phytate were also determined using appropriate technique. The result of proximate analysis indicated that leaves and seeds had high crude protein $(18.00 \%$ and $14.63 \%)$, dry matter (94.78\% and $90.98 \%)$, Ash (7.00\% and $8.02 \%)$, crude fiber for both leaves $(12.75 \%)$ and seed $(28.44 \%)$ and the ether extract was $(4.60 \%)$ and $(5.03 \%)$ for leaves and seeds respectively. Mineral analysis indicated the Crotalaria retusa leave and seeds contained some essential mineral such as $\% \mathrm{P}(0.37 \%)$ leave and $(0.47 \%)$ seeds, $\% \mathrm{~K}(0.97 \%, 0.68 \%), \% \mathrm{Mg}$ $(0.48 \%, 0.64 \%), \% \mathrm{Ca}(0.58 \%, 0.78 \%)$ and $\mathrm{Fe}(76.10 \mathrm{mg} / \mathrm{kg})$ for leaves and $(70.10 \mathrm{mg} / \mathrm{kg})$ seeds of Crotalaria retusa. The leaves and seeds of Crotalaria retusa had low concentration of anti-nutrient factors; phytate $(0.01 \%)$ leave and $(0.06 \%)$ seed, oxalate $(0.07 \%)$ leave and $(0.09 \%)$ seed, tannin contents were $(0.02 \%)$ and $(0.05 \%)$ for leaves and seeds respectively. The overall results suggested that Crotalaria retusa leaves and seeds were of high nutritionally quality due to high protein and mineral contents with low presence of anti-nutritional factors.
\end{abstract}

\section{Subject Areas}

Plant Science 


\section{Keywords}

Crotalaria retusa Leaves, Seed, Proximate, Mineral Contents and Anti-Nutritional Factors

\section{Introduction}

Pasture is a major agricultural resource that supports both intensive and extensive livestock made of production. One of the major problems confronting animal production in Nigeria, more especially in arid and semi-arid zone is wide variability in the quality of feed over the feeding/grazing period, attributable to variation in weather and climate [1].

At peak of dry season, with the depletion of crop residues and forage supply from native rangeland coupled with overgrazing and bush fire, the consequences are inadequate supply feed and loss of body weight, low milk yield and poor reproductive performance of livestock [2].

Ruminant animals contribute substantially to the world's human food supply, especially in the marginal areas of the tropics where population is on the increase [3]. However, for these animals to play a leading role in food supplies, their nutrient requirement will have to be given adequate attention. Forage is the cheapest and major nutritional component in the diets of ruminant animals, particularly in rural and sub-urban areas of the tropics [4].

They are mostly sourced from native or natural pastures which are generally poor in terms of quality and quantity that can sustain animals throughout the year [1]. Efforts to improve animal nutrition during the dry season have led to a shift to the use of forage browse legumes.

Rattle box (Crotalaria retusa) plant is a rather common leguminous plant that seems less considered in pasture and range production in the ruminant's enterprise. Crotalaria retusa plant is a promising feed resource in the tropics because the plant is in full leaf and green at the peak of the dry season when other feeds are typically scarce [5].

This study was therefore designed to screen for proximate composition, mineral contents and anti-nutrient factors present in the leaves and seeds of Crotalaria retusa.

\section{Materials and Methods}

\subsection{Experimental Site}

The experiment was carried out at Teaching and Research Farm, Pasture Unit of Oyo State College of Agriculture and Technology, Igboora in the derived Savannazone of Nigeria. The College is located within $7^{\circ} 15^{\prime}$ North and $3^{\circ} 30^{\prime}$ East of the equator with average annual rainfall of $1278 \mathrm{~mm}$ and average annual temperature of $27^{\circ} \mathrm{C}[6]$. 


\subsection{Collection of Plant Materials}

The leaves and seeds of Crotalaria retusa L. were obtained from pasture demonstrated unit, Teaching and Research Farm of the college. The seeds were then separated from their shells/pod having dried appropriately, milled with blender and stored in air-tight containers until required for analysis.

\subsection{Proximate Analysis}

The leaves and seeds were analyzed for moisture content, ash, crude fat, crude protein and crude fiber which were determined in accordance with the standard methods of the [7]. Crude fat was determined by exhaustively extracting samples in a soxhlet apparatus using any hydrous diethyl ether as the solvent.

Crude protein determination involved the use of routine Kjeldhal nitrogen assay (NX 6.25). Crude fibre estimates were obtained from the loss in weight on ignition of dried residue following the digestion of fat free sample with 1.25\% each of sulphuric acid and sodium hydroxide solution under specified condition.

\subsection{Mineral Analysis}

The minerals such as $\mathrm{K}, \mathrm{P}, \mathrm{Mg}$, $\mathrm{Ca}$ and Fe were determined by the atomic absorption spectrophotometric method. The samples which were digested in acid solution of $\mathrm{HNO}_{3}$ and perchloric acid [8] were passed through Atomic Absorption Spectrophotometry (AAS) using different lamps and calibrated or different micronutrients. Potassium was determined through lame photometer after acid digestion. Phosphorus was determined spectrophotometrically using the Vendatessolution [9].

\subsection{Anti-Nutritional Factor}

Oxalic acid was estimated quantitatively by redox titration with standard potassium permanganate according to the procedure of Day and Underwood [10]. Saponin was determined using the method similar to that of Hudson and El-Difrawl [11], phytic acid determined in accordance with the procedure of Ruales and Nair [12]. Tannic acid was determined in accordance with the procedure of AOAC [7].

\subsection{Statistical Analysis}

The data collected were subjected to analysis of variance in a completely randomized design and Student $\mathrm{T}$ test was used to separate the means.

\section{Results and Discussions}

\subsection{Result}

\subsubsection{Proximate Composition}

Table 1 shows the proximate contents of Crotalaria retusa leaves and seeds. Higher percentage value of dry matter contents were observed for both leaves (94.78\%) and seeds (80.98\%). The percentage crude protein contents recorded 
Table 1. Proximate contents of Crotalaria retusa leaf and seeds.

\begin{tabular}{ccc}
\hline Proximate (\%) & Leaves (\%) & Seeds (\%) \\
\hline Dry matter & 94.78 & 90.98 \\
Crude protein & 18.00 & 14.63 \\
Ash & 7.00 & 8.02 \\
Ether extract & 4.60 & 5.03 \\
Crude Fibre & 16.75 & 20.40 \\
\hline
\end{tabular}

for both leaves (18.00\%) and seeds (14.63\%) were favourably higher. Higher values of crude protein recorded for both leave and seeds in the present study were above 7\% CP requirement for ruminant animals which will provide ammonia requirement by the rumen micro-organisms to support optimum microbial activity.

The crude fibre content indicated that seeds (28.44\%) contained high value compared to leaves (12.75\%). Seeds (5.03\%) contained appreciable amount of ether extract compared to (4.60\%) for the leaves of Crotalaria retusa. The ash content of seed $(8.02 \%)$ was evidently higher than that of leaves $(7.00 \%)$ of the Crotalaria retusa.

\subsubsection{Mineral Analysis}

The mineral analysis of both leaves and seeds of Crotalaria retusa indicated their richness in Phosphorus, Potassium, Magnesium, Calcium and Iron as presented in Table 2. The levels of Phosphorus (0.37\%), Potassium (0.97\%), Magnesium $(0.48 \%)$, Calcium $(0.58 \%)$ and Iron $(76.10 \mathrm{mg} / \mathrm{kg})$ in leaves of Crotalaria retusa compared to seeds that had. Phosphorus (0.47\%), Potassium (0.68\%), Magnesium $(0.64 \%)$, Calcium $(0.78 \%)$ and Iron $0.0(70.10 \mathrm{mg} / \mathrm{kg})$.

\subsubsection{Level of Anti-Nutrient Factors}

Table 3 shows the level of anti-nutrient factors present in both leaves and seeds of Crotalaria retusa. The anti-nutrient contents for Phytate (0.02\%), Oxalate $(0.09 \%)$ and Tannin $(0.05 \%)$ were observed to be numerically higher in seed of Crotalaria retusa compared to leaves for phytate $(0.02 \%)$, oxalate $(0.07 \%)$ and tannin $(0.02 \%)$ respectively.

\subsection{Discussion}

\subsubsection{Proximate Composition}

High dry matter contents were obtained for both seeds and leaves of Crotalaria retusa. The percentage ranged (90.98\% - 93.78\%), indicating high shelf - life of the leave and seed, hence long storage would not lead to much spoilage due to its susceptibility to microbial attack especially of drying. The percentage Crude Protein of leaves (18.00\%) and seeds (14.63.30\%) were above 17.5\% CP recorded for Stylosanthes hamata leaves [13]. The higher crude protein recorded for both seed and leaves of Crotalaria retusa in the present study was above 7\% CP requirement for ruminant animal which will provide ammonia requirement by the 
Table 2. Mineral composition of seed and leaves of Crotalaria retusa.

\begin{tabular}{ccc}
\hline Mineral Content & Leaves & Seeds \\
\hline Phosphorus (\%) & 0.37 & 0.47 \\
Potassium (\%) & 0.97 & 0.68 \\
Magnesium (\%) & 0.48 & 0.64 \\
Calcium (\%) & 0.58 & 0.78 \\
Iron (mg/kg) & 76.10 & 70.10 \\
\hline
\end{tabular}

Table 3. Anti-nutritional factor present in seed and leaves of Crotalaria retusa.

\begin{tabular}{ccc}
\hline Anti-nutritional factor & Leaves (\%) & Seeds (\%) \\
\hline Phytate & 0.01 & 0.06 \\
Oxalate & 0.07 & 0.09 \\
Tannin & 0.02 & 0.05 \\
\hline
\end{tabular}

rumenmicro-organism to support optimum microbial activity. Both leaves and seeds could serve as potential protein supplement and will enhance the intake and utilization of low quantity grass and fibrous crop residue by ruminants. The importance of protein to animal health cannot be overemphasized, therefore Crotalaria retusa seeds and leaves could be used as feed protein supplement.

The Ash content value of Crotalaria retusa were (7.00\%) leave and (8.02\%) in seed and was higher than. (0.11\%) reported for Mucuna utilis leaves by [14] and above 5.0\% in Bracystegia eurycome hanms seed [15]. The ash values for both seed and leaves obtained for the present study fell within the range of 3.0\% 9.65\% [16]. Ash content useful in assessing the quality of mineral element present in the Crotalaria retusa leave and seeds. This suggests that the samples could be a better source of essential and has minerals needed for good body development.

Ether extract content of Crotalaria retusa were (5.03\%) in seed and [4.60\%] in leave which were higher than (1.89\%) reported for Canavalia ensiformis leaves [13]. Also higher than the $1.9 \%$ Ether extract for lablab seed [17]. The values are also higher than the ether extract content $(2.10 \%$ and $1.41 \%)$ of pigeon pea seed reported by [18] also higher than Phosphocarpus leave (4.10\%) reported by [19].

The Crude fiber content of Crotalaria retusa leave (16.75\%) and seeds (20.40\%) were above compared with (14.80\%) of Mucuna utilis leaves reported by [14] and $23.80 \%$ for Stylosanthes hamata [20]. Persea ameneans seed contained $3.10 \%$ which lower than $8.10 \%$ recorded for Clitoria ternatea seed [21]. The crude fiber content of both seed and leaves samples fell within the range of $15 \%-20 \%$ recommended for improved intake and production in finishing ruminant [22].

\subsubsection{Mineral Composition}

The mineral analysis of a plant gives the idea of possibility either the plant 
should be used for any feeding trial purpose. The phosphorus content for leave $(0.37 \%)$ and seed $(0.47 \%)$ were higher compared to the NRC recommended value of $0.15 \%$ for Phosphorus [23]. The level of Phosphorus in both the seed and the leaves of Crotalaria retusa were consistently above the $0.2 \%$ level which would satisfy livestock dietary maintenance requirement [23].

Phosphorus play an important role in carbohydrate, lipid and amino and metabolism. Phosphorus is also required for blood coagulation (thromboplastim) satisfactory bone calcification optimum growth rate and optimum utilization of both calcium and phosphorus.

The value of Potassium $(\% \mathrm{~K})$ in both seed $(0.68 \%)$ and leave $(0.97 \%)$ were higher than $(0.46 \% \mathrm{~K})$ for Canavalia ensiformis leaves by [13] and for seed of Brachystegia eurycoma harms $(0.25 \%)$. In the present investigation the level of $\% \mathrm{~K}$ in Crotalaria retusa leaves was over $0.18 \%$ recommended for grazing animals [24]. However, it has been suggested that ruminants with high productivity may require $\% \mathrm{~K}$ level above $(1.0 \%)$ under stress particularly heat stress [25]. Potassium help to maintain body weight and regulate water and electrolyte balance in the blood and tissue [23].

Magnesium ( $\mathrm{Mg}$ ) content for leave $(0.48 \%)$ and seeds $(0.64 \%)$ both were higher than value $0.20 \%$ reported for Canavalia ensiformis leave by [13]. The higher forage and seed $\mathrm{Mg}$ level found in this present study were above $0.12 \%$ $0.20 \%$ of requirement of ruminants diet suggested by [23]. Magnesium is an important mineral element in connection with its role in circulatory disease such as ischemic heart disease and calcium metabolism in above [26].

The Calcium ( $\mathrm{Ca}$ ) content of both seed $(0.78 \%)$ and leave $(0.58 \%)$ were higher than $(0.09 \%)$ observed in Cannavalia ensiformis leave by [13]. The leaves and seed $\mathrm{Ca}$ values found in this study were considered adequate for the optimum performance of ruminants. The values of both leaves $(0.58 \%)$ and seed $(0.78 \%)$ of \% Ca for Crotalaria retusa would meet the theoretical $\mathrm{Ca}$ requirement of $0.30 \%$ Ca diet needed for all forms of production in ruminants [27]. Calcium helps in the regulation of muscle contraction required by kid, weaner and is useful for bone and teeth development [28].

The Iron $(\mathrm{Fe})$ content of Crotalaria retusa leave $(76.10 \mathrm{mg} / \mathrm{Kg})$ and seed $(70.0$ $\mathrm{mg} / \mathrm{Kg})$ were higher compared to $(10.58 \mathrm{mg} / 100 \mathrm{~g})$ recorded for Iron content of Mucuna utilis leaves. Iron levels obtained for Clitoria leaves and seeds content in the present study were above $(50 \mathrm{mg} / \mathrm{kg})$ sufficient for requirement of ruminants for optimal performance and also above the critical levels of $\mathrm{Fe}$ in animal tissue $(30-50 \mathrm{mg} / \mathrm{kg}$ ) [25]. Iron is said to be an important element in the diets of pregnant animal, nursing animal, infant and other conditions disease [29].

\subsubsection{Anti-Nutritional Factor}

Table 3 show the level of antinutritional factors in the Crotalaria retusa leaves and seed. The tannin obtained in the Crotalaria retusa leave $(0.02 \%)$ and seed $(0.05 \%)$ were lower than the $5 \%$ at which goats may reject feed [30]. Tannin at this level protects liable plant proteins in the rumen and consequently increases 
the supply of high quality protein into the duodenum [30].

Phytate and oxalate content for both seed and leave of Crotalaria retusa are $(0.06 \%)$ and $(0.01 \%)$ while oxalate was $(0.07 \%)$ leave and $(0.09 \%)$ for seed, both were low in anti-nutritional contents. The phytic value was lower than the range of $3.74 \%$ and $3.24 \%$ reported for some legumes in Nigeria (31) while the oxalate contents was lower than $0.52-0.82 \mathrm{mg} / 100 \mathrm{~g}$ reported for some legumes consume by goats in Nigeria.

However, due to microbial fermentation in the rumen, ruminants, including goats can consume considerable amounts of plant with high oxalate content without adverse effects.

\section{Conclusion and Recommendation}

It can be concluded from the results of this study that the Crotalaria retusa leaves and seed appeared to have the potential as feed supplements. Higher content of protein and minerals combined with relatively low levels of anti-nutrient would make them good protein supplements to poor quality roughages especially during the dry season of the derived savanna zone of Nigeria.

\section{Conflicts of Interest}

The authors declare no conflicts of interest regarding the publication of this paper.

\section{References}

[1] Alalade, J.A. (2012) Effect of Legume Intercropping Legumes and Application of Manure on Herbage Yield and Nutritive Value of Native Panicum maximum. Ph.D Thesis, Department of Animal Production and Health, LAUTECH, Ogbomoso LAUTECH.

[2] FAO (1983) The Role of Food Safety in Health and Development: Report of a Joint FAO/WHO Expert Committee on Food Safety. Meeting, Geneva, May 30-June 6 1983.

[3] Alalade, J.A., Akingbade, A.A., Akanbi, W.B., Gbadamosi, J., Okeniyi, G., Ajibade, A.O. and Akanji, K.A. (2014) Herbage Yield and Nutritive Quality of Panicum maximum Intercropped with Different Legumes. International Journal of Science, Environment and Technology, 3, 224-232.

[4] Akinsoyinu, A.O. and Onwuka, C.F.I. (1988) Mineral Constituents of Some Browse Plants Used in Ruminant Feeding in Southern Nigeria. Nigeria Journal of Animal Production, 15, 57-62.

[5] Lakpini, C.A.M. (2002) Manual for Small Ruminant Production. In Nigeria, a Manual Presented at a Stakeholder Workshop in National Animal Production Research Institute (NAPRI) ABU Zaria, 11-35.

[6] Sanusi, W.A. (2011) Effect of Poverty on Parturition in Non-Farm Activity in Ibarapa Local Government Area of Oyo State. Nigeria IJAART, 1 \& 2, 86-95.

[7] AOAC (1990) Official Method of Analysis Association of Official Analytical Chemists. 15th Edition, Washington, D.C., USA, 66-88.

[8] Toth, S.J., Prince, A.L., Wallace, A. and Mikkenlsen, D.J. (1948) Rapid Quantitative Determination of Eight Mineral Elements in Plant Tissue Systematic Procedure In- 
volving Use of a Flame Photometer. Soil Science, 66, 459-466. https://doi.org/10.1097/00010694-194812000-00006

[9] Sekine, T., Sasakawa, T., Morita, S., Kimura, T. and Kuratom, K. (1965) cf. Laboratory Manual for Physiological Studies of Rice. In: Yoshida, S., Forno, D., Cook, J.B. and Gomez, K.A., Eds., Pub. International Rice Research Institute, Manila, India.

[10] Day, R.A. and Underwood, A.L. (1986) Quantitative Analysis. 5th Edition, Prentice Hall Publication, Upper Saddle River, 701.

[11] Hudson, B.J.F. and El-Difrawl, E.A. (1981) The Sapoagenins of the Seeds of Four Lupin Species. Journal of Plant Foods, 3, 181-186. https://doi.org/10.1080/0142968X.1979.11904227

[12] Ruales, J. and Nair, B.M. (1993) Saponins, Phytic Acid, Tannins and Protease Inhibitors in Quinoa (Chenopodium quinoa, Wild) Seeds. Food Chemistry, 48, 137-143. https://doi.org/10.1016/0308-8146(93)90048-K

[13] Akinlade, J.A., Farinu, G.O., Taiwo, A.A., Aderinola, O.A., Adebayo, T.A., Ojebiyi, O.O. and Olaniran, O.A. (2007) Agronomic and Nutritive Evaluation of Jack Bean (Canavalia ensiformis) for Fodder in the Derived Savannah Zone of Nigeria. International Journal of Agricultural Research, 2, 1059-1063.

https://doi.org/10.3923/ijar.2007.1059.1063

[14] Ujowundu, C.O., Okafor, O.E., Agha, N.C., Nwaogu, L.A., Igwe, K.O. and Igwe, C.U. (2010) Phytochemical and Chemical Composition of Combretum zenkeri Leaves. Journal of Medicinal Plant Research, 40, 965-968.

[15] Ajayi, O.B., Akomolafe, S.F. and Adefioye, A. (2014) Proximate Analysis, Mineral Contents, Amino Acid Composition, Anti-Nutrients and Phytochemical Screening of Brachystegiacurycoma. Harms and Piper guinense Schum and Thonn. American Journal of Food and Nutrition, 2, 11-17.

[16] Okoli, I.C., Ebere, C.S., Emenalom, O.O., Uchengbu, M.C. and Esonu, B.O. (2001) Indigenous Livestock Paradigms Revisited 11: An Assessment of the Proximate Value of Most Preferred Indigenous Browses of South Eastern Nigeria. Tropical Animal Production Investigation, 4, 99-107.

[17] Osman, M.A. (2007) Effect of Different Processing Methods on Nutrient Composition, Antinutritonal Factors, and in Vitro Protein Digestibility of Dolichos Lablab Bean (Lablab purpuresus (L) Sweet). Pakistan Journal of Nutrition, 6, 299-303.

[18] Ogundipe, S.O., Abeke, F.O., Sekoni, A.A., Dafwang, I.I. and Adeyinka, I.A. (2003) Effect of Cooking Duration on the Utilization of Lablab Purpereus Beans by Pullet Chicks. Proceedings of the 28th Annual Conference of Nigeria Society of Animal Production, Ibadan, Vol. 28, 233-234.

[19] Alalade, J.A., Akinlade, J.A., Aderinola, O.A., Fejemisin, A.N., Muraina, T.O. and Amoo, T.A. (2016) Proximate, Mineral and Anti-Nutrient Contents in Psophocarpus tetragonolobus (L) DC (Winged Bean) Leaves. British Journal of Pharmaceutical Research, 10, 1-7. https://doi.org/10.9734/BJPR/2016/22087

[20] Akinlade, J.A., Farinu, G.O., Aderinola, O.A., Ojeleye, T.Y. and Tona, G.O. (2004) Nutritive Value of Stylosanthes guianensis and Hamata in Derived Savannah Zone of Nigeria. Science Focus, 9, 145-149.

[21] Arukwe, U., Amadi, B.A., Duru, M.K.C., Agomuo, E.N., Adindu, E.A., Odika, P.C., Lele, K.C., Egejuru, L. and Anudike, J. (2012) Chemical Composition of Persea americana Leaf, Fruit and Seed. International Journal of Research and Reviews in Applied Sciences, 11, 355-358.

[22] Buxton, D.R. (1996) Quality Related Characteristics of Forages as Influed by Plant 
Environment and Agronomic Factors. Animal Feed Science and Technology, 59, 37-49. https://doi.org/10.1016/0377-8401(95)00885-3

[23] NRC (1985) Nutrients Requirements of Beef Cattle. 17th Edition, National Academy Press, Washington DC.

[24] McDowell, L.R. (1985) Calcium, Phosphorus and Flourine. In: McDowell, L.R., Ed., Nutrition of Grazing Ruminants in Warm Climates, Academic Press, Orlando, 189-212.

[25] Khan, Z.I., Ashraf, M., Hussain, A. and McDowell, L.R. (2005) Seasonal Variation of Trace Elements in a Semiarid Veld Pasture. Communications in Soil Science and Plant Analysis, 37, 1471-1484. https://doi.org/10.1080/00103620600585914

[26] Hassan, L.G. and Umar, K.J. (2006) Nutritional Value of Balsam Apple (Momordica balsamina L.) Leaves. Pakistan Journal of Nutrition, 5, 522-529. https://doi.org/10.3923/pjn.2006.522.529

[27] ARC (1980) The Nutrients Requirements of Ruminant Livestock. 4th Edition, CAD International, Wallingford, 73-310.

[28] Margaret, L. and Vickery, B. (1997) Plant Products of Tropical Africa. Macmillan in College, London.

[29] Anonymous (1980) Analytical Methods for Atomic-Absorption Spectrophotometry. Perkin-Eimer Corporation, Norwalk.

[30] Mcleod, M.N. (1974) Plant-Tannins. Their Role in Forage Quality. Nutrition Abstracts and Reviews, 11, 803-815.

[31] Oke, O.L. (1969) Oxalic Acid in Plants and in Nutrition. World Review of Nutrition and Dietetics, 10, 263-303. https://doi.org/10.1159/000387569 